research

\title{
Salinity and photoperiod modulate pubertal development in Atlantic salmon (Salmo salar)
}

\author{
Michelle C Melo ${ }^{1,2}$, Eva Andersson ${ }^{3}$, Per Gunnar Fjelldal ${ }^{4}$, Jan Bogerd ${ }^{2}$, Luiz R França', \\ Geir Lasse Taranger ${ }^{3}$ and Rüdiger W Schulz ${ }^{2}$ \\ 'Department of Morphology, Institute of Biological Sciences, Federal University of Minas Gerais, \\ Av. Antônio Carlos 6627, 31270-901 Belo Horizonte, Minas Gerais, Brazil \\ ${ }^{2}$ Reproductive Biology Group, Division Developmental Biology, Department of Biology, Faculty of Sciences, \\ Utrecht University, Kruyt Building, Room W-606, Padualaan 8, NL-3584 CH Utrecht, The Netherlands \\ ${ }^{3}$ Institute of Marine Research, PO Box 1870, Nordnes, 5817 Bergen, Norway \\ ${ }^{4}$ Institute of Marine Research, Matre Research Station, 5984 Matredal, Norway
}

Correspondence should be addressed to R W Schulz Email

r.w.schulz@uu.nl

\begin{abstract}
The Atlantic salmon shows substantial life cycle plasticity, which also applies to the timing of puberty. While it is characterized by the activation of the brain-pituitary-gonad axis, many morphophysiological aspects of puberty and the influence of environmental conditions, such as water salinity, are not well understood in fish. Here, 12-month-old Atlantic salmon coming from an out-of-season smoltification regime in December were exposed to freshwater (FW) or seawater (SW) at $16{ }^{\circ} \mathrm{C}$ to stimulate puberty under a 24-h constant light (LL) or $12 \mathrm{~h}$ light:12 h darkness (LD) photoperiod. These four treatment groups (FWLL, SWLL, FWLD, and SWLD) were studied from January to March. Next to 11-ketotestosterone (11-KT) plasma levels, the expression of pituitary genes ( $g n r h r 4, f s h b$, and $/ h b$ ) and spermatogenesis was quantified. When spermatogonial proliferation started, fshb mRNA levels increased steeply and began to decrease when spermatogonial mitosis approached completion and most germ cells had reached meiotic or post-meiotic stages. Conversely, Ihb mRNA levels increased progressively during spermatogenesis. Most males in all treatment groups matured, but exposure to SW resulted in the strongest stimulation of the onset of spermatogenesis and elevation of pituitary gnrhr4 and fshb mRNA levels. Later on, the LD photoperiod accelerated, irrespective of the salinity, the completion of spermatogenesis, associated with higher Ihb mRNA and 11-KT plasma levels than in the LL groups. We find that both salinity and photoperiod modulated different aspects of spermatogenesis, and resulted in a differential activation of pituitary and testis functions; SW stimulating the onset and the shorter photoperiod the completion of spermatogenesis.
\end{abstract}

Key Words

- Atlantic salmon

- salinity

- photoperiod

- pituitary gene expression

- spermatogenesis
Journal of Endocrinology (2014) 220, 319-332

\section{Introduction}

The Atlantic salmon (Salmo salar) is a cold-water-adapted, anadromous teleost that experiences seasonal changes in temperature and photoperiod in fresh and seawater (SW) and exhibits a substantial plasticity in the timing and routing of its life cycle (Taylor 1991, Hutchings \&
Jones 1998). This plasticity also applies to puberty that can occur at different stages of the life cycle (Taranger et al. 2010). While it is known that environmental conditions like photoperiod and water temperature can affect the timing of puberty, the specific roles of these

Published by Bioscientifica Ltd. 
conditions and their possible interactions are not well established (Fjelldal et al. 2011). Moreover, sexual maturation occurs at different water salinities in salmon, such as at full salinity in the ocean (grilse and multi seawinter salmon), as precocious parr in freshwater (FW; Jonsson \& Jonsson 2007), and also in fjords or estuarine areas with brackish water (Jonsson et al. 2001). However, information on the possible effects of salinity on puberty is missing.

In salmon aquaculture, early puberty is a common problem compromising somatic growth, harvest quality, and fish welfare (Bromage et al. 2001, Taranger et al. 2010). Despite these negative impacts, in particular, affecting males that normally reach puberty at a lower age and smaller size than females, there is yet limited knowledge on both physiological mechanisms triggering puberty in salmon or other fishes and modulatory effects of environmental factors on the functioning of these mechanisms (Taranger et al. 2010). Recently, Fjelldal et al. (2011) found that high $\left(16^{\circ} \mathrm{C}\right)$ water temperature in combination with continuous light induced puberty at the postsmolt stage just after SW transfer. This induced postsmolt maturation provides an excellent experimental model to study physiological processes involved in puberty and to study how these processes are modulated by different environmental factors.

We used this model to the examine effects of salinity and photoperiod on entry and completion of puberty in males. Prior to commencing the experimental treatments at the postsmolt stage, an out-of-season photoperiod regime was applied in FW from October to December to induce smoltification (Stefansson et al. 1991). Samples were collected every 3 weeks during the next 3 months (January to March) to analyze the expression of key genes in the pituitary, plasma androgen levels and to evaluate spermatogenesis quantitatively. This unique data set allowed new conclusions as regards physiological processes involved in the onset as well as completion of spermatogenesis and modulation of these processes by water salinity and photoperiod.

\section{Materials and methods}

\section{Experimental design}

The experiments took place at Matre Research facility $\left(61^{\circ} \mathrm{N}\right)$, which is part of the Institute of Marine Research, Bergen (Norway). On September 29, 1600 Atlantic salmon presmolts were distributed over 16 experimental tanks of 5001 with 100 fish per tank (body weight $151 \pm 19 \mathrm{~g}$ (mean \pm s.D.). The fish were kept under constant light (LL) in FW until October 20, when an out-of-season smoltification regime (Berge et al. 1995, Arnesen et al. 2003) was initiated: 6 weeks of a short-day photoperiod LD (0900-2100 h; 12:12) was followed by 4 weeks of LL from December 1 . Water temperature was maintained at 11.8 $\pm 0.7^{\circ} \mathrm{C}$ until January 4 . On January 5 , after completion of smoltification, eight tanks were moved back to LD 12:12 while the remaining eight tanks were kept on LL. The body weight was $376 \pm 155 \mathrm{~g}$ at this time. The tanks were supplied with either FW or SW 35ppt (SW), and either LL or LD, creating four experimental groups (FWLL, FWLD, SWLL, and SWLD; Fig. 1) with four replicate tanks per group. To stimulate maturation (Fjelldal et al. 2011), the water temperature was increased in all tanks on

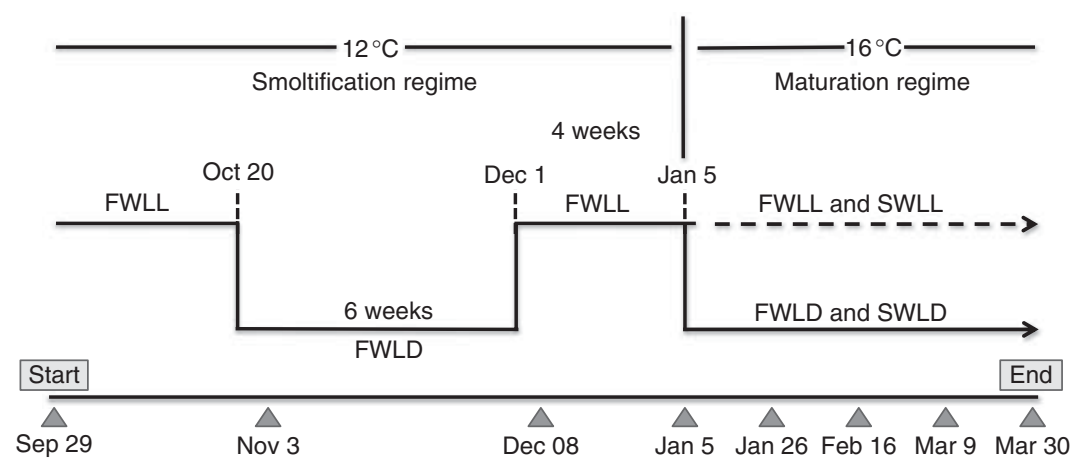

Figure 1

Experimental design to investigate the effects of different environmental conditions on sexual maturation of Atlantic salmon postsmolts. All fish underwent a smoltification regime at $12{ }^{\circ} \mathrm{C}$ from September 29 to January 5 . Fish were then split into four experimental groups with four replicate tanks, each receiving a particular maturation regime from
January 5 to March 30 by elevating water temperature to $16^{\circ} \mathrm{C}$. The fish in the four different groups were exposed to the following environmental conditions: FWLL, SWLL, FWLD and SWLD, where FW, fresh water; SW, salt water; LL, continuous light and LD, $12 \mathrm{~h}$ light: $12 \mathrm{~h}$ darkness. Samples were collected on the dates indicated by arrowheads.

Published by Bioscientifica Ltd 
January 12 and was maintained at $15.5 \pm 1.1^{\circ} \mathrm{C}$ until completion of the experiment on March 30. Fish were sampled every 3 weeks both during the smoltification regime and after establishing the four experimental groups for collection of tissue and blood samples (Fig. 1).

\section{Sampling}

Fish were killed in water containing $10 \mathrm{mg} / \mathrm{l}$ of the anesthetic metomidate (Syndel, Victoria, BC, Canada). Body weight was recorded, blood was collected from the caudal veins, and gonads were excised. Testes were weighed and fixed in Bouin for $24 \mathrm{~h}$ and stored in $70 \%$ ethanol. Blood was centrifuged and plasma was stored at $-80^{\circ} \mathrm{C}$. The gonadosomatic index (GSI) was calculated as GSI $(\%)=$ gonad weight $(\mathrm{g}) \times 100 /$ total body weight $(\mathrm{g})$. The pituitary was excised, snap-frozen in liquid nitrogen, and then stored at $-80{ }^{\circ} \mathrm{C}$ until RNA extraction.

\section{Measurement of plasma concentration of 11-ketotestosterone}

Prior to RIA, individual plasma samples were mixed with Milli-Q water (containing $0.05 \%(\mathrm{w} / \mathrm{v}) \mathrm{NaN}_{3}$ ) in the ratio $1: 2$ and incubated at $80{ }^{\circ} \mathrm{C}$ for $1 \mathrm{~h}$. After centrifugation (at $21000 \boldsymbol{g}$ for $30 \mathrm{~min}$ ), the supernatant was stored at $-20^{\circ} \mathrm{C}$ until RIA. Quantification of 11-ketotestosterone (11-KT) plasma levels was carried out using a specific RIA (Schulz 1985).

\section{Testis histology and morphometry}

For routine histological analysis, sections of $5 \mu \mathrm{m}$ were stained with periodic acid-Schiff and hematoxylin/eosin. The progress through spermatogenesis was analyzed quantitatively using the software ImageJ and ten nonoverlapping digital images per fish were randomly taken (Olympus-AX-70; Nikon Digital Camera DXM 1200) at $600 \times$ magnification. Using a grid with 180 intersections, the germ cells under the intersections were identified and counted. The results are expressed as the average number of germ cells counted in the different phases of spermatogenesis. We distinguished undifferentiated type A spermatogonia (SPGA und; single cells with no or very little heterochromatin in the nucleus, one or two prominent nucleoli, and a nuclear diameter of $\sim 15 \mu \mathrm{m}$ ), differentiated type A spermatogonia $\left(\mathrm{SPGA}_{\text {diff; }}\right.$ two or more cells with some heterochromatin and a nuclear diameter of $\sim 10 \mu \mathrm{m}$ ), and type B spermatogonia (SPGB; groups of cells with a high amount of heterochromatin and a nuclear diameter below $8 \mu \mathrm{m}$ ). Counts for primary and secondary spermatocytes were combined. Different stages of spermiogenesis were counted collectively as spermatids. Spermatozoa in the lumen of the seminiferous tubules were counted when the intersection fell on the sperm head.

Next to the quantitative evaluation, we noted for each male the furthest developed germ cell type, being either SPGA $A_{\text {und, }}$ SPGA $A_{\text {diff, }}$ SPGB, spermatocytes and/or spermatids (SC-ST), or spermatozoa (SZ). Finally, when free spermatozoa filled the tubular lumen, the males were qualified as spermiated (SP). The typical histological appearance of these stages is presented in Supplementary Figure 1 , see section on supplementary data given at the end of this article.

\section{Immunohistochemistry}

Proliferation of germ (SPGA $\mathrm{und}_{\text {und }}$ aPGA $\left.\mathrm{A}_{\text {diff }}\right)$ and Sertoli cells was assessed by immunocytochemical localization of the proliferation marker phosphorylated histone H3 (pH3; Hendzel et al. 1997, Cobb et al. 1999). Three sections of $5 \mu \mathrm{m}$ that were at least three sections apart from each other were used for detection of $\mathrm{pH} 3$ as described by Almeida et al. (2008), except that the primary antibody was detected by undiluted HRP-conjugated goat antirabbit IgG (Brightvision Immunologic, Duiven, The Netherlands) for $30 \mathrm{~min}$. To quantify proliferation, 25 non-overlapping fields were randomly chosen and analyzed using a Nikon Digital Camera DXM 1200 connected to Olympus-AX-70 at $1000 \times$ magnification. The number of pH3-positive cells was counted in the 25 fields and expressed as the average of cells per field.

\section{RNA isolation, CDNA synthesis, and real-time, quantitative PCR}

Frozen salmon pituitaries were homogenized in $1 \mathrm{ml}$ tubes containing Trizol reagent from the IPrepTM Trizol PLUS RNA Kit (Invitrogen) and zirconium oxide beads in a Precellys 24 Homogenizer (Bertin, Villeurbanne, France), followed by RNA isolation. Next, cDNA synthesis was performed with $2 \mu \mathrm{g}$ of each total RNA sample using a Superscript VILO cDNA synthesis kit (Invitrogen). To estimate the relative salmon gnrhr4 (see Table 1), lhb, and fshb (Andersson et al. 2013) mRNA levels, TaqMan assays were performed, as described previously (de Waal et al. 2008). The levels of elongation factor ef1a mRNA (Olsvik et al. 2005) served as endogenous control RNA, which remained stably expressed under the different experimental conditions.

Published by Bioscientifica Ltd. 
Table 1 Primers and TaqMan fluorogenic probe used in real-time PCR assays to determine the relative gnrhr4 mRNA levels in Atlantic salmon pituitaries

\begin{tabular}{|c|c|c|c|c|}
\hline Target & $\begin{array}{l}\text { Genbank accession } \\
\text { number }\end{array}$ & $\begin{array}{l}\text { Primer } \\
\text { name }\end{array}$ & Sequence $5^{\prime}-3^{\prime}$ & PCR efficiency (\%) \\
\hline gnrhr4 & KF225730 & $\begin{array}{l}\text { Fw } \\
\text { Rv } \\
\text { Pr }\end{array}$ & $\begin{array}{l}\text { TCAACCCACTGGCGATCAAT } \\
\text { CGTGATGGTCACACTGTGGAATA } \\
\text { AGTGTGATTCTGTCTGTTCCCCAGATGCTG }\end{array}$ & 101.8 \\
\hline
\end{tabular}

All TaqMan assays were performed in $10 \mu \mathrm{l}$ reaction volumes and their $\mathrm{Cq}$ values were determined in a 7900HT Real-Time PCR System (Applied Biosystems) using default settings. Relative mRNA levels, calibrated to the first sampling, were calculated as reported previously (Bogerd et al. 2001, Good et al. 2012).

\section{Statistical analysis}

Data were analyzed using STATISTICA v11 (StatSoft, Inc. 2012; Tulsa, OK, USA). To achieve homogeneity of variance, data were $\log 10$ transformed; GSI data were arcsin transformed. The number of germ cells was analyzed by one-way ANOVA followed by Tukey's multiple comparisons test, or two-tailed unpaired Student's $t$-test when necessary, with a significance level of $P<0.05$. As regards GSI, 11-KT levels, and gene expression data presented according to the sampling date, the time-wise effects within the treatment groups were also tested with one-way ANOVA followed by Tukey's multiple comparisons test, using all males until January 5, and using the maturing males within each treatment group from January 26. In addition, all males from January 5 were compared with the maturing males in the four treatment groups at January 26 with one-way ANOVA followed by Dunnet's post hoc test, using the January 5 sample as controls. Subsequently, effects of salinity and photoperiod on maturing males from January 26 were analyzed by two-way ANOVA within each sampling date, and in all males by stage of germ cell development by oneway ANOVA, followed by Newman-Keuls post hoc test comparing groups formed according to the most advanced germ cell stage. The GSI values of the eight males sampled on January 5 showed a bimodal distribution $(<0.04$ vs $>0.05 ; n=4$ in both modes). After sorting the data on pituitary gene expression, androgen plasma levels, and proliferation activity in an immature and a maturing group, the differences between these groups were analyzed by two-tailed unpaired Student's $t$-test $(P<0.05)$. The incidence of maturation among the groups was compared with a $\chi^{2}$ test using the SWLL group as control and significance level of $P<0.05$. Data on the graphs are presented as mean \pm s.E.M.

\section{Results}

\section{Morphological analysis of testis maturation}

Until January 5, SPGA were the only germ cells present (Fig. 2b), composed predominantly of SPGA $\mathrm{und}_{\text {with only a }}$ small fraction of SPGA diff (Fig. 3a). Thereafter, SPGB (Fig. 2c) or meiotic and postmeiotic (spermatids and spermatozoa) germ cells (Fig. 2d) were also present in most males. However, between three and 16 males sampled from January 26 to March 30 stayed immature and showed testes with SPGA only (Fig. 2a). The SWLL group showed the highest incidence of maturation (93\%), although $70-80 \%$ maturation was found in the other groups. Analyzing Sertoli and germ cell proliferation in testes containing only SPGA revealed mainly single cell proliferation (Fig. $2 b$ inset) with no (Sertoli cells) or minor (SPGA) differences between sampling dates (data not shown). In testes recruited into maturation, also smaller and larger germ cell clones were proliferating (Fig. 2c inset), heralded by a shift to the prominent presence of SPGA $\mathrm{A}_{\text {diff }}$ and SPGB in all treatment groups on January 26 (Fig. 3b). Compared with the fish kept in FW, the fish kept in SW (hatched and cross-hatched columns) had significantly more germ cells that had progressed to the stage of SPGB, at the expense of SPGA (Fig. 3b). Comparing the FW groups, the LD photoperiod had a slight stimulatory effect, since we observed less SPGA $A_{\text {diff }}$ and a tendency to more SPGB than in the FWLL group (Fig. 3b).

From February 16, meiotic (primary and secondary spermatocytes) and postmeiotic (spermatids and spermatozoa) germ cells were found in the maturing testes of all the four groups (Fig. 3c, d, and e). The counts for SPGA became very small and ranged between 0.3 and 1.1 germ cell per field in all groups, with somewhat higher values in the FWLL and lower values in the SWLL and FWLD groups (data not shown). The counts for SPGB and spermatocytes were similar among groups (Fig. 3c), i.e. spermatogonial proliferation and meiosis proceeded in all groups.

Published by Bioscientifica Ltd. 

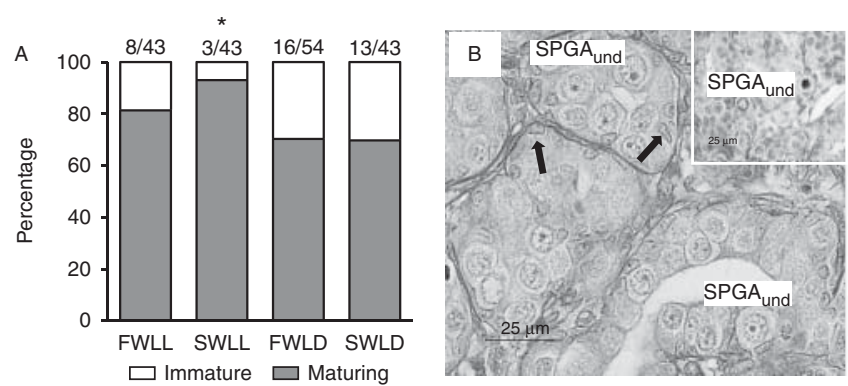
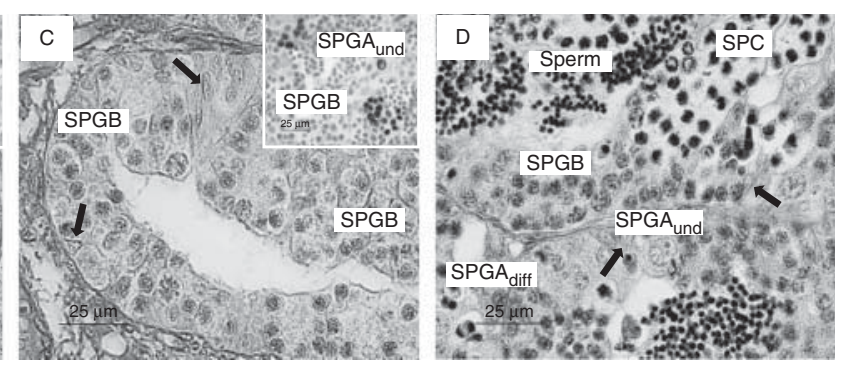

\section{Figure 2}

Percentage of males committed to sexual maturation, quantification of cell proliferation in the testis, and testicular histology of Atlantic salmon postsmolts. (a) Percentage of salmon males recruited into sexual maturation. The first number above the bar graph represents the total number of immature fish sampled between January 26 and March 30, the second number represents the total number of fish analyzed. Asterisk indicates the group, which showed a higher percentage of maturing males $(P<0.05$, $\chi^{2}$-test). (b) Histology of an immature testis sampled on January 5 , containing mainly undifferentiated type A spermatogonia (Aund). A low level of mainly single cell proliferation activity is found represented as brown staining in cell

A different pattern emerged from analyzing the samples collected in March (Fig. 3d and e). While exposure to SW induced earlier formation of SPGB (January 26) and postmeiotic cells (February 16) than in the FW groups, in March, fish under LD showed higher counts for spermatozoa and lower counts for spermatogonia and spermatocytes compared with fish under LL, irrespective of the salinity. On March 30, the number of spermatids had also decreased, indicating that completion of spermiogenesis was approaching. Spermatogenesis still proceeded well in the SWLL and FWLL groups since nuclei (inset). (c) Salmon testis recruited into sexual maturation, sampled on January 26, showing type B spermatogonia (SPG B) and clearly elevated cell proliferation activity (inset), including single cells, small (top left on inset), and large groups (down right on inset) of germ cells. (d) Testis containing germ cells at different stages of spermatogenesis sampled on February 16. Aund, undifferentiated type $A$ spermatogonia; Adiff, differentiated type $A$ spermatogonia; SPG B, type B spermatogonia; SPC, spermatocyte; FW, fresh water; SW, salt water; LL, continuous light; LD, 12 h light: 12 h darkness. Arrows in (b), (c) and (d) indicate Sertoli cell nuclei. A full colour version of this figure is available online at http://dx.doi.org/10.1530/JOE-13-0240.

spermatozoa appeared (FWLL) or increased further (SWLL) on March 9 (Fig. 3d). This development continued toward March 30 (Fig. 3e) but the number of spermatozoa was still lower than in the LD groups.

\section{Overall effects of salinity and photoperiod on recruitment into puberty}

The data collected from maturing males were subjected to a two-way ANOVA, testing for effects of salinity, photoperiod, and their interactions within each sampling
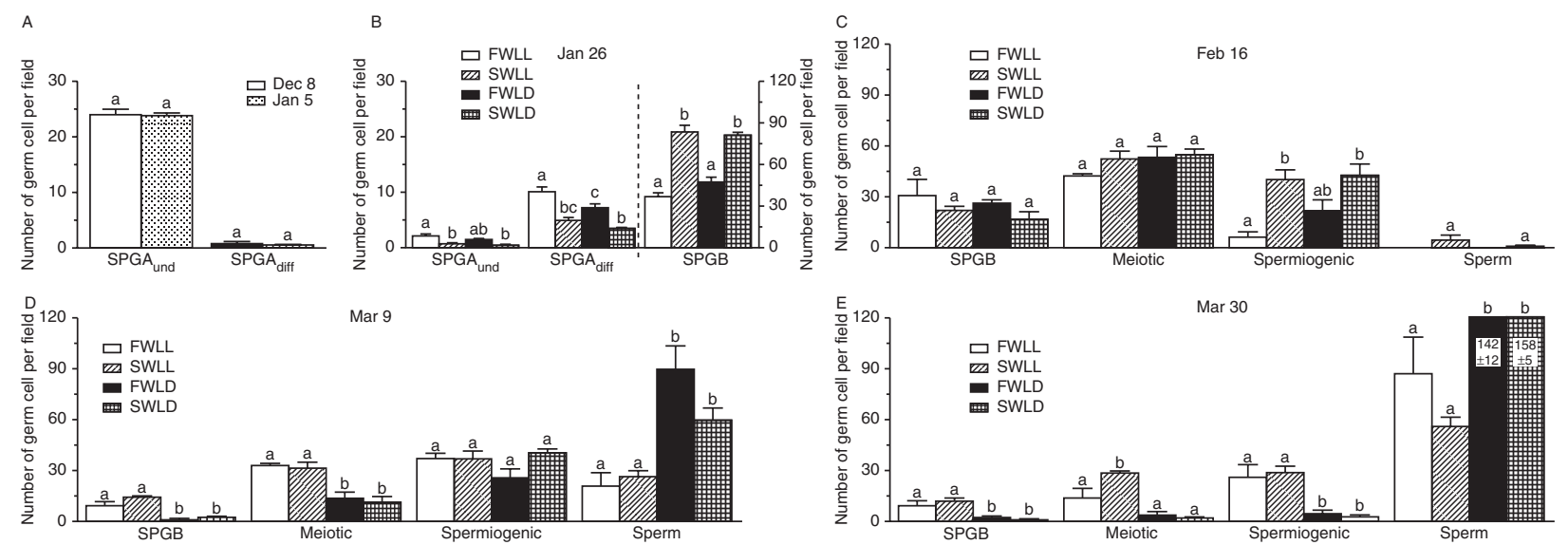

\section{Figure 3}

Quantitative evaluation of spermatogenesis. The bar graphs show the mean numbers of different types of germ cells counted per microscopic field at $600 \times$ magnification and their S.E.M. from immature fish (a) sampled on December 8 (black bars) and January 5 (grey bars) and at different dates during the maturation regime $(b, c, d$ and e) when different treatment groups were exposed to freshwater (FW) or salt water (SW), constant light
(LL) or $12 \mathrm{~h}$ light:12 $\mathrm{h}$ darkness (LD) resulting in the following four groups: FWLL, SWLL, FWLD and SWLD (legends indicated in the graphs). Bars labeled with different letters showed statistically significant differences in their mean values $(P<0.05$; one-way ANOVA followed by Tukey's test). Aund, undifferentiated type $A$ spermatogonia; Adiff, differentiated type $A$ spermatogonia; SPG B, type B spermatogonia. 
Table 2 Significant $(P<0.05)$ differences using two-way ANOVA in GSI, plasma androgen, or pituitary gene expression levels resulting from exposure to different water salinities or photoperiod regimes are indicated by the capital letters $\mathrm{S}$ or $\mathrm{P}$ respectively according to sampling date. A significant interaction is indicated by the capital letter I

\begin{tabular}{|c|c|c|c|c|}
\hline & Jan 26 & Feb 16 & March 9 & March 30 \\
\hline GSI & $S, P$ & $P$ & $S, P$ & $S, P$ \\
\hline 11-KT & $P$ & $P$ & $P$ & $P$ \\
\hline gnrhr4 & $\mathrm{S}, \mathrm{P}$ & $\mathrm{S}, \mathrm{P}$ & $\mathrm{P}$ & S, P, I \\
\hline fshb & $\mathrm{S}, \mathrm{P}$ & $P$ & $\mathrm{P}, \mathrm{I}$ & $\mathrm{S}, \mathrm{P}$ \\
\hline Ihb & $\mathrm{P}$ & $P$ & $\mathrm{P}$ & $\mathrm{P}$ \\
\hline
\end{tabular}

date from January 26 until March 30. A summary of the analysis is given in Table 2 and the detailed results from the two-way ANOVA on effects of salinity and photoperiod within each sampling date are provided in Supplementary Table 1, see section on supplementary data given at the end of this article. The photoperiod regime significantly modulated the maturational response on all sampling dates and parameters studied. In addition, significant but more selective effects of salinity were found, showing that GSI and gnrhr4 and $f$ shb mRNA levels but not plasma androgen and pituitary lhb mRNA levels were modulated. Significant interactions between the effects of salinity and photoperiod were noted for $f s h b$ on March 9 and for gnrhr4 on March 30.

\section{GSI and 11-KT plasma levels}

The average GSI values increased gradually between September 29 and January 5 (Fig. 4a inset). On January 26 and onward, only maturing fish were taken into account for calculating GSI values. The GSI increased significantly in the maturing males in all treatment groups by January 26 (one-way ANOVA followed by Dunnet's post hoc test using all males in January 5 as controls). The two groups kept in SW showed 1.6- or 2.1-fold higher values than the respective FW groups (Fig. 4a), indicating that transfer to SW further stimulated the onset of testis growth. The GSI increased five- to tenfold until February 16 in all groups, reaching values between 3.9 and 9.6. While the GSI in fish in SW was no longer different from their FW counterparts, the fish kept under LD showed 1.7to twofold higher GSI levels than their LL counterparts. On March 9, the GSI values in the two LD groups were slightly $(8-7.4 \%)$ or clearly $(9.6-5.6 \%)$ lower compared with 3 weeks earlier, while the GSI reached high values of
7.7 and $9.6 \%$ in the two LL groups. Toward March 30, the GSI values decreased clearly in the groups under LD (Fig. 4a) but only slightly (1.1- and 1.2-fold) in the groups under LL. As more germ cells had developed into spermatozoa in the LD groups on March 30 (see Fig. 3e), the more strongly decreasing GSI is in line with the loss of cellular material during spermiogenesis. Maximum GSI values were reached at different sampling dates but showed a similar range $(7.6-9.6 \%)$ in all treatment groups.

Average 11-KT plasma levels ranged between 1 and $1.3 \mathrm{ng} / \mathrm{ml}$ from September to December (Fig. 4b inset). On January 5, a sixfold increase in the mean 11-KT levels was observed. On January 26, 11-KT plasma levels had increased again significantly in maturing males under LD and an alike tendency was found under LL, reaching mean values between 10 and $20 \mathrm{ng} / \mathrm{ml}$ (Fig. 4b). A similar pattern was observed on February 16, with no significant changes compared with the previous sampling. However, on March 9 and 30, both LD groups showed 11-KT plasma levels exceeding two- to threefold those of their LL counterparts (Fig. 4b).

\section{Pituitary gene expression}

gnrhr4 Pituitary gnrhr4 mRNA levels increased gradually from September to January 5, reaching statistical significance on January 5 (Fig. 5a), and further increased two- to 4.6-fold by January 26 in all groups. The two SW groups showed 1.5- to 1.8-fold higher expression levels than their FW counterparts. On February 16, the groups kept in SW still showed significantly higher (1.7- and 2.1-fold) gnrhr4 mRNA levels than the FW groups. A different pattern emerged when analyzing the March samples, where fish under LD showed 1.5- and 2.3-fold higher gnrhr4 mRNA levels than under LL (March 9), although on March 30, the SWLL group had reached the high level of the LD groups as well.

Gonadotropin $\boldsymbol{\beta}$-subunits The first significant increase in $f s h b$ mRNA levels was recorded on January 5 (Fig. $5 \mathrm{~b}$ inset). The $f s h b$ mRNA levels kept increasing strongly (six- to 24-fold) in maturing fish and reached very high levels already on January 26 in all groups (Fig. 5b). High levels (0.7- to 1.4-fold change compared to January 26) were maintained until February 16 with no statistical differences between the groups, before decreases to a third of the previous levels were recorded on March 9 in the FWLD group, and both LD groups that continued to decline toward the final sampling when the levels were

Published by Bioscientifica Ltd 
A
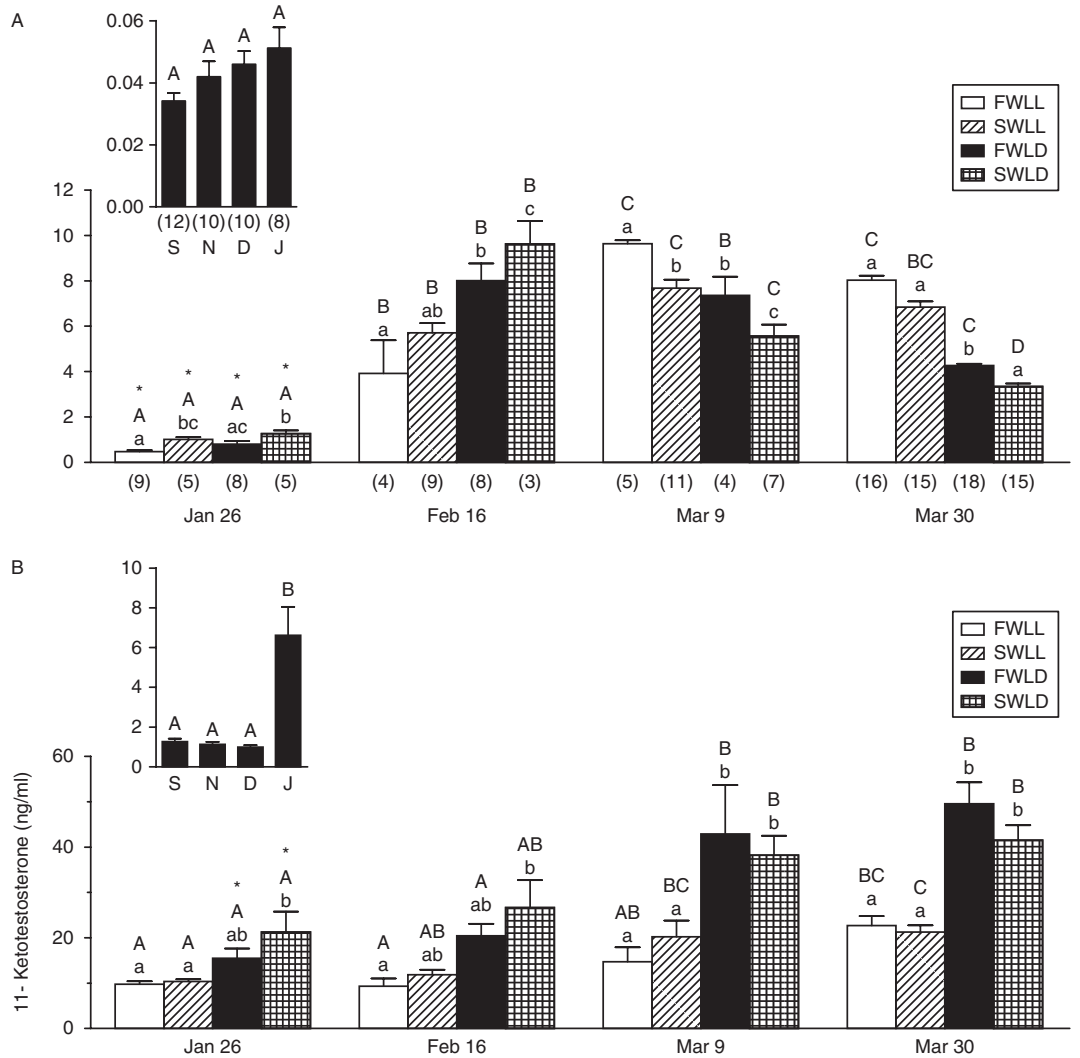

Figure 4

Gonadosomatic index (GSI; a) and 11-ketotestosterone plasma levels (b) of male postsmolt Atlantic salmon during the progression of spermatogenesis. The inset bar graph shows the values of fish sampled between September (S) 29 and January (J) 5 . Bars show the mean values and their S.E.M. from the different treatment groups: FWLL, SWLL, FWLD and SWLD (legends are indicated in the graphs). Capital letters in the inserts and in the figures denotes samples that are significantly different time-wise
$(P<0.05$; one-way ANOVA followed by Tukey's post hoc test). Asterisks above the bars on January 26 denote values that are significantly different from the January 5 sample (one-way ANOVA followed by Dunnet's post hoc test using January 5 as controls). Lower case letters denote significant differences between treatments within each sampling date from January 26 onwards ( $P<0.05$; two-way ANOVA followed by SNK post hoc test).

The number of individuals per group is indicated under the respective bars. again halved (Fig. 5b). The LL groups, on the other hand, had maintained elevated $f s h b$ mRNA levels on March 9 (0.8- to 1.4-fold change compared to the previous sampling). Thereafter, the level in fish under LL decreased toward March 30 only among those kept in FW. The fshb mRNA levels in the SWLD group on January 26 were higher than in all other groups, while on March 30 the lowest levels were found in the FWLD group that ranged significantly below its LL counterpart also on March 9.

Also lhb mRNA levels increased significantly for the first time in the pituitaries sampled at the beginning of January. From then on, $l \mathrm{hb}$ mRNA levels kept increasing in the maturing fish, and elevated levels were maintained until the end of March. A separation of the groups exposed to different photoperiods became evident already on January 26, with higher levels in the LD groups. This difference kept increasing such that in all the following samplings, pituitary $l h b$ mRNA levels of the LD groups were twice as high as in the LL groups.

The speed of germ cell development depended on the salinity and photoperiod conditions experienced by the maturing males. To obtain the developmental profiles across treatment groups, we sorted the data of all males according to the most developed type of germ cell present in the testis (Fig. 6). Stage-dependent, significant differences were found for all parameters. In general, low levels were characteristic of fish with testes containing SPGA, and significant increases were associated with the first appearance of SPGB. Except for $f s h b$ mRNA levels, which already reached a high plateau at this early stage, all other parameters further increased significantly toward meiosis and beyond (Fig. 6). The fshb transcript levels also contrasted with the other parameters by starting to decrease with the appearance of spermatozoa. A rather 
A

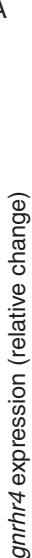
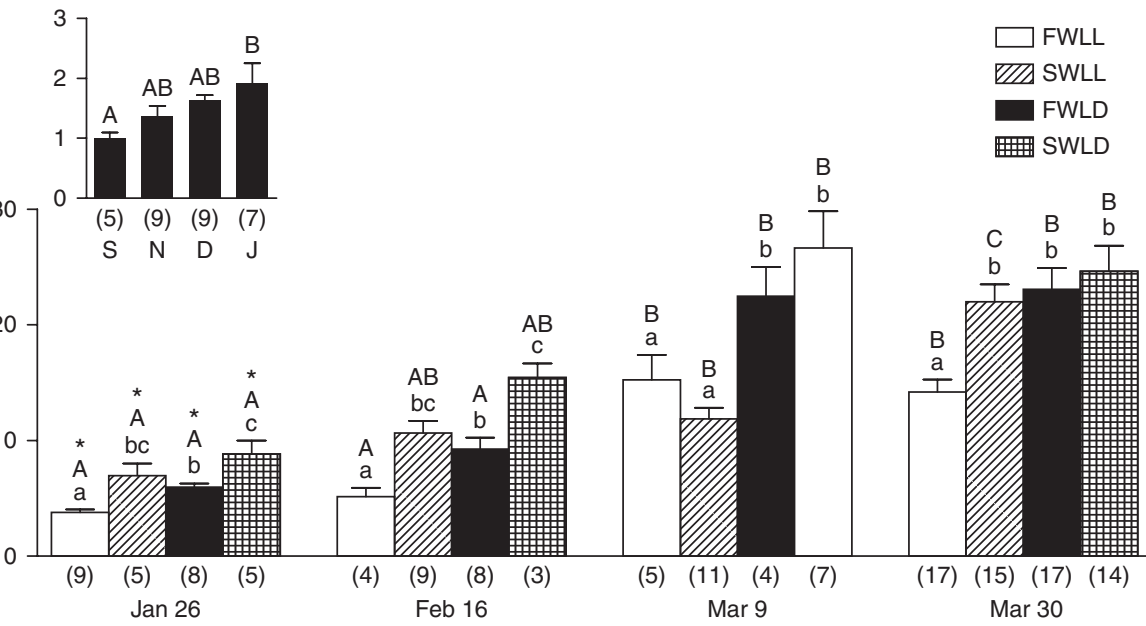

B
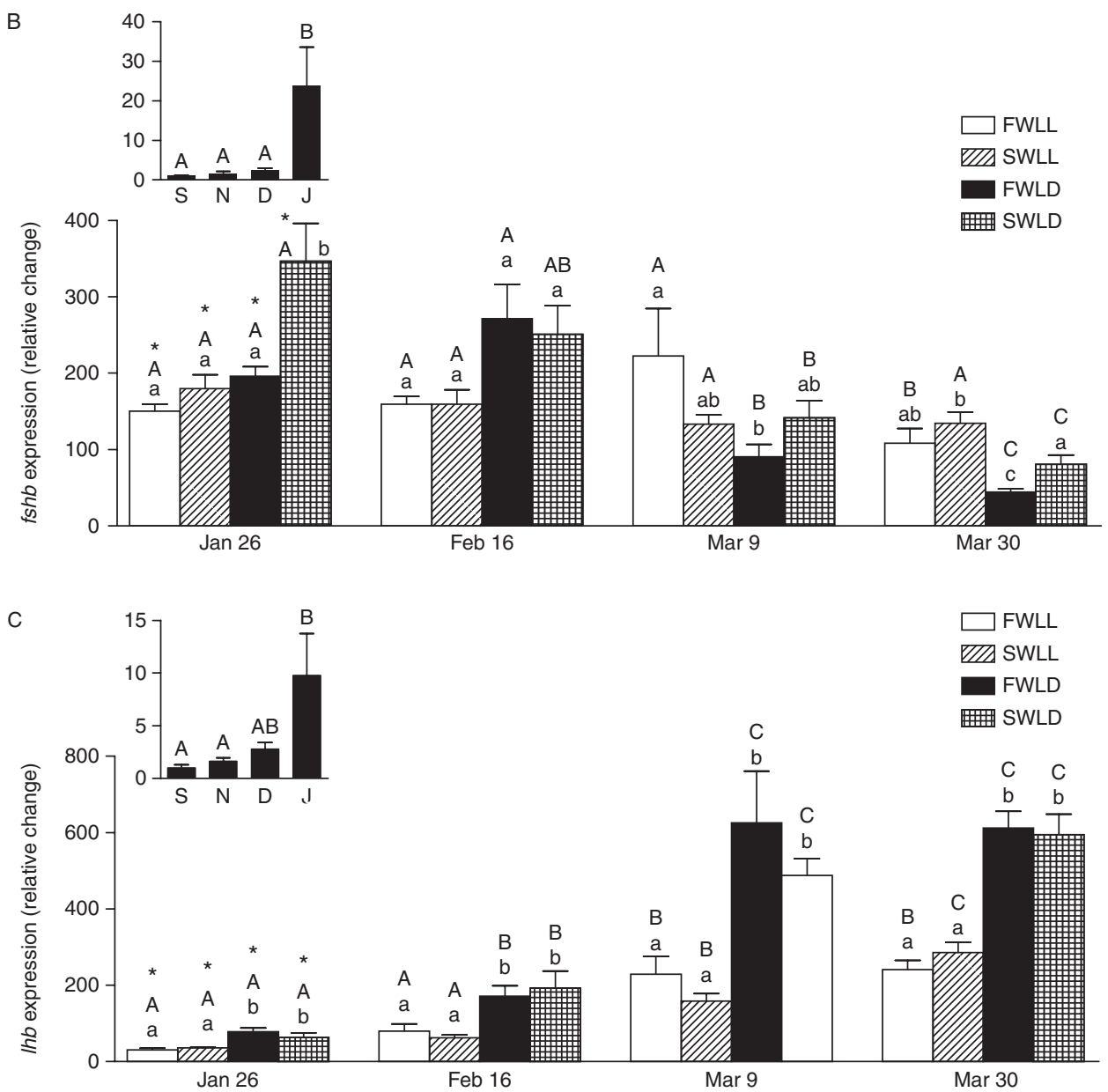

Figure 5

Relative pituitary mRNA levels of the gnrhr4 (a), fshb (b) and lhb (c) genes in Atlantic salmon postsmolts. The inset bar graphs show the pituitary mRNA levels of fish sampled between September (S) 29 and January (J) 5. Bars show the mean values and their S.E.M. from the different treatment groups: FWLL, SWLL, FWLD and SWLD (legends are indicated in the graphs). Capital letters in the insets and in the figures denote samples that are significantly different time-wise $(P<0.05$; one-way ANOVA followed by
Tukey's post hoc test). Asterisks above the bars on January 26 denote values that are significantly different from the January 5 sample (one-way ANOVA followed by Dunnet's post hoc test using January 5 as controls). Lower case letters denote significant differences between treatments within each sampling date from January 26 onwards $(P<0.05$; two-way ANOVA followed by SNK post hoc test). The number of individuals per group is indicated under the respective bars. 
limited variation was typical for this data set, suggesting that the stage of spermatogenesis, but not the treatments, had a strong influence on the changes observed. Hence, salinity and photoperiod conditions affected the timing of development, but not the mass of germ cells formed (GSI),
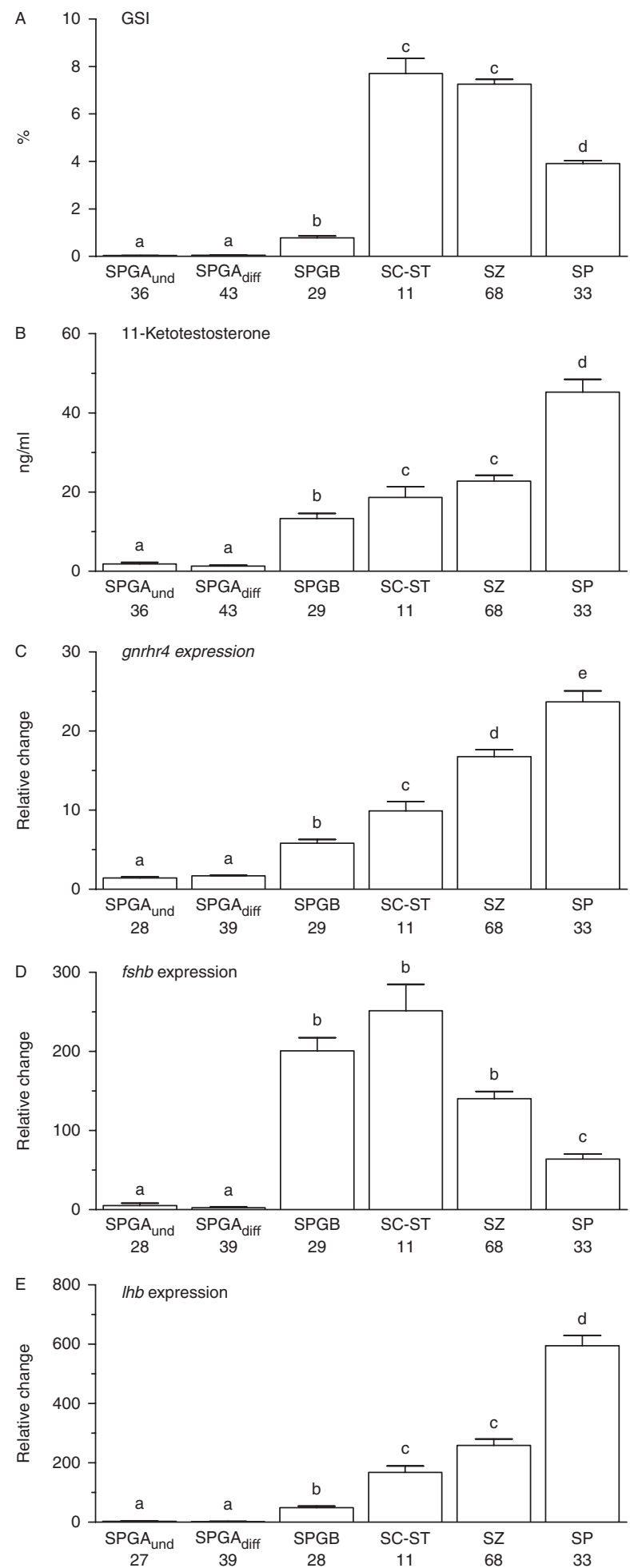

http://joe.endocrinology-journals.org DOI: $10.1530 / J O E-13-0240$ plasma androgen, or pituitary gene expression levels, typically found at specific stages of spermatogenesis.

On January 5, just before the maturation regime with elevated water temperature started, increases in gene expression and plasma androgen levels were recorded, but changes in testicular histology were not observed (all testes contained SPGA; see Fig. 3a). The GSI values of the eight males sampled showed a bimodal distribution (see above Statistical analysis). Sorting proliferation, pituitary gene expression, and plasma androgen levels according to the GSI values (below $0.04 \%$, considered immature; above $0.05 \%$, considered maturing; Fig. 7) revealed statistically significant differences for all parameters. It appears that at the very beginning of puberty, the pituitary gonadotrops became activated in part of the males sampled on January 5 that moreover showed elevated plasma androgen levels and increased testicular cell proliferation activity.

\section{Discussion}

There is a substantial plasticity in both age and size at puberty in fish. The timing of recruitment into puberty is sensitive to changes in environmental conditions such as photoperiod, food availability, or temperature. The Atlantic salmon is a prominent example in this regard and can reach sexual maturation as parr, grilse, or multi sea winter salmon (Taylor 1991, Hutchings \& Jones 1998, Garcia de Leaniz et al. 2007), and recent work has shown that postsmolt maturation can be induced immediately after smoltification (Fjelldal et al. 2011). While many studies have investigated physiological mechanisms triggering puberty in fish, original aspects of this study are to study effects of different salinities (in combination with two photoperiod regimes) on the timing of pubertal development, and the detailed morphological analysis of testis development that accompanies analyzing pituitary key gene expression and plasma androgen levels.

\section{Figure 6}

Gonadosomatic index (GSI; a), plasma 11-ketotestosterone (11KT; b), relative pituitary mRNA levels of gnrhr4 (c), fshb (d) and lhb (e) in all sampled fish sorted according to the most advanced germ cell stage; Aund, Adiff, SPGB, spermatocytes and/or spermatids (SC-ST), or spermatozoa (SZ). When free, spermiated spermatozoa filled the tubular lumen and represented the by far dominating germ cell type, the males were assigned to the group spermiation (SP). Lower case letters denote significant differences between the stages $(P<0.05$; one-way ANOVA followed by SNK post hoc test). The number of individuals per group is indicated under the respective bars.

Published by Bioscientifica Ltd. 

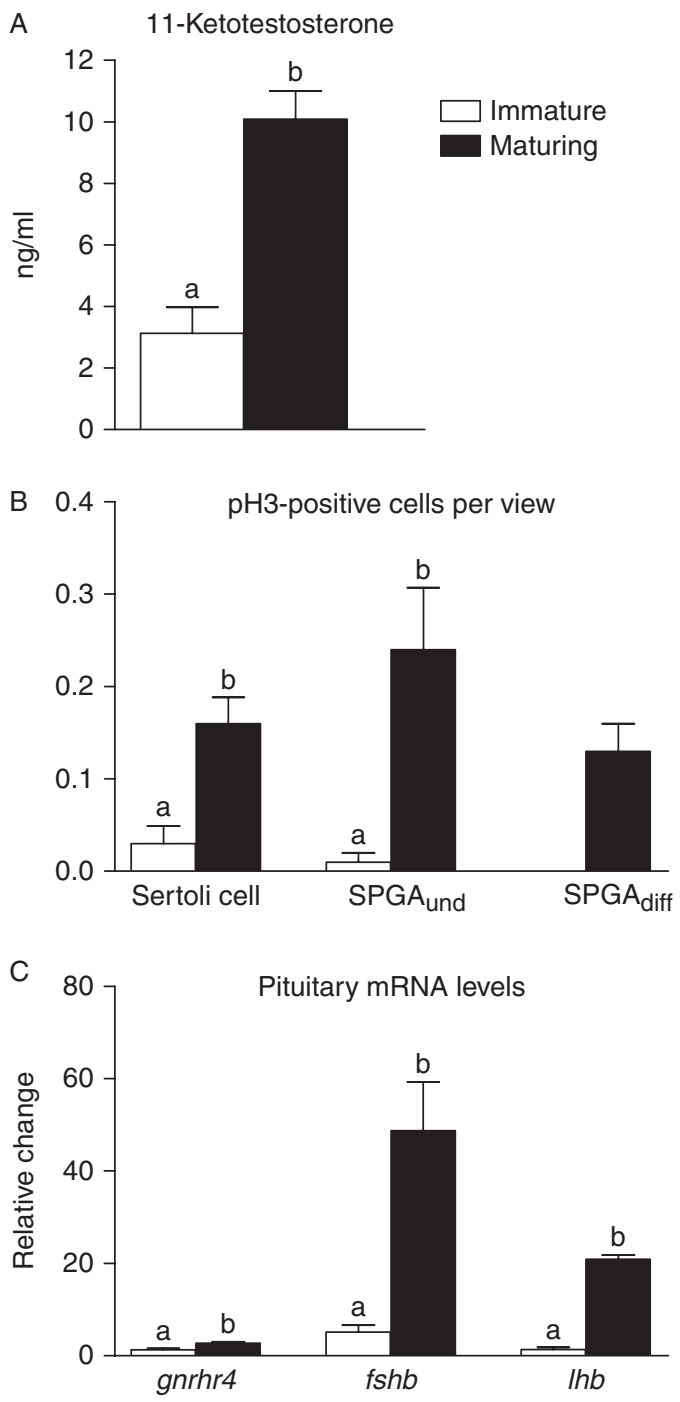

Figure 7

Analyses of different parameters (11-ketostestorone, testicular cell proliferation and pituitary gene expression) in male Atlantic salmon postsmolts. The bar graphs show the mean values and their S.E.M. in immature fishes (open bars) and maturing fishes (black bars) on January 5 . Bars labeled with different letters showed statistically significant differences in their mean values $(P<0.05$; two-tailed unpaired Student's $t$-test). Aund, undifferentiated type A spermatogonia; Adiff, differentiated type A spermatogonia.

Our analyses showed that some (mainly single cell) proliferation is found in immature testes from males sampled before or after the start of the maturation regime. We propose that this proliferation activity reflects the allometric growth of the gonads but is not associated with a recruitment into maturation. Accordingly, the GSI in this group of individuals remained low.

Pituitary gene expression, plasma androgen levels, and testicular proliferation activity were clearly elevated by January 5 in half of the males (Fig. 7). This early activation prior to the start of the maturation regime was somewhat surprising but might reflect a stimulatory effect of the continuous light treatment used at the end of the smoltification regime; similar photoperiod conditions stimulated the onset of both parr and postsmolt maturation (Thrush et al. 1994, Duncan \& Bromage 1998, Fjelldal et al. 2011, Skilbrei \& Heino 2011). Also the high body weight (c. 200-600 g in this study, compared to normally $<100 \mathrm{~g}$ ) and the late time of the year for the induced, out-of-season smoltification may have allowed maturation to start. Last but not least, the smoltification regime also included a 6-week LD photoperiod (Fig. 1) that may have increased the incidence of maturation. In masu salmon parr, a short photoperiod accelerated maturation, associated with an activation of preoptic GNRH neurons, and an increase in pituitary Fsh levels (Amano et al. 1999, 2001). Collectively, these conditions may have activated the brain-pituitary axis at the beginning of January. Planas et al. (1993) and Planas \& Swanson (1995) showed that Fsh stimulated testicular 11-KT release, probably mediated by the Fsh receptor, which is also expressed by Leydig cells in fish (Ohta et al. 2007, García-López et al . 2009, 2010, Chauvigné et al. 2012). Elevated 11-KT plasma levels were associated with the appearance of SPGB in rainbow trout (Oncorhynchus mykiss; Scott \& Sumpter 1989) and Chinook salmon (Oncorhynchus tshawytscha; Campbell et al. 2003). This study is the first to show in an in vivo setting in fish that increased proliferation activity of Sertoli cells as well as spermatogonia type $A_{\text {und }}$ and $A_{\text {diff }}$ are early signs of recruitment into puberty at the beginning of January. Also with respect to $f s h b$ mRNA levels, Fsh, but not $\mathrm{Lh}$, is elevated in the blood of salmonids at the onset of pubertal development (Swanson et al. 1989, OppenBerntsen et al. 1994, Gomez et al. 1999), and fshb transcript levels and Fsh plasma levels were quite well correlated during puberty in male rainbow trout (Gomez et al. 1999). This opens the possibility that Fsh - next to activating androgen release - has stimulated Sertoli and germ cell (SPGA) proliferation to support recruitment into puberty. Luckenbach et al. (2010) showed that pituitary gnrhr transcript levels were upregulated in male coho salmon (Oncorhynchus kisutch) preparing to enter puberty, an observation in agreement with our finding. Finally, as mentioned earlier, Amano et al. $(1999,2001)$ reported activation of GNRH neurons and increased pituitary Fsh contents in response to environmentally stimulated puberty in masu salmon. Collectively, these data suggest that recruitment into puberty may involve GNRH receptor-mediated activation of Fsh release that

Published by Bioscientifica Ltd. 
stimulates androgen production and germ and Sertoli cell proliferation.

The majority of postsmolt males had committed to sexual maturation on January 26 , as indicated by the lower number of $A_{\text {und }}$ spermatogonia and the higher number of $\mathrm{A}_{\mathrm{diff}}$ and SPGB. Although a detailed morphofunctional evaluation of spermatogenesis in Atlantic salmon is still missing, studies on three other salmonid species have shown that spermatogonia go through six to eight rounds of mitotic divisions prior to entering meiosis (reviewed by Schulz \& Nóbrega (2011)). Therefore, we can expect within 3 weeks a mitotic cell cycle every 2-3 days during the development from $\mathrm{A}_{\text {und }}$ to late SPGB in Atlantic salmon.

Androgen levels were further elevated at the end of January in the LD groups, tended to increase also in the LL groups, and $f s h b$ mRNA levels reached maximum values in a steep increase from the beginning of January. The steroidogenic activity of Fsh in fish has been discussed above. Classically, the production and release of gonadotropin would be stimulated by GNRH, acting via the GNRH receptor. While both pituitary gnrhr4 and fshb mRNA levels were elevated in all groups on January 26 , this was most prominently the case in the SW groups, as revealed by two-way ANOVA, and we interpret the higher number of SPGB found in these groups as reflecting stronger pro-differentiation signals (Fsh, androgen) stimulating spermatogenesis. Next to the salinity effect, it is possible that the shift to the shorter photoperiod provided an additional stimulus, perhaps via the GNRH neurons (Amano et al. 1999), which could explain the strongest increase in $f s h b$ transcript and plasma androgen levels in the SWLD group on January 26.

Future work will have to clarify the physiological mechanisms mediating SW-induced increases in pituitary gnrhr4 transcript levels and the accelerated production of SPGB. Two observations are interesting to note in this context. First, hyperosmotic stress increased growth hormone-mediated, hepatic insulin-like growth factor 1 production (Meier et al. 2009), which may have increased pituitary gnrhr mRNA levels (Luckenbach et al. 2010). Secondly, hyperosmotic stress following SW exposure might also have stimulated vasopressin release (Balment et al. 2006), which in turn can directly stimulate testicular androgen release (Rodríguez \& Specker 1991).

In general, spermatogenesis and steroidogenesis are regulated by gonadotropins in vertebrates. As has been discussed earlier, Fsh plasma levels are elevated in salmonid fish at the onset as well as during most of the rapid growth phase of the pubertal testis (Suzuki et al. 1988, Swanson et al. 1989, Oppen-Berntsen et al. 1994). The steep increase in $f s h b$ mRNA levels in all groups at the onset of puberty, an observation made in maturing salmon parr as well (Maugars \& Schmitz 2008a), strongly supports the view that Fsh is the gonadotropin of major relevance for the onset of puberty. Primary tissue culture studies using immature Japanese eel testis suggested that spermatogonial proliferation and differentiation was solely mediated by the steroidogenic effect of Fsh (Ohta et al. 2007), but direct effects of Fsh on Sertoli cells are possible in other fishes. In zebrafish, Fsh downregulated Sertoli cell gene expression of anti-Müllerian hormone (amh) independent of sex steroid action (Skaar et al. 2011). As Amh inhibited both germ cell differentiation and steroid production (Skaar et al. 2011), Amh downregulation by Fsh is important for the sustained activity of the two main testicular functions. Downregulation of testicular amh mRNA levels was also reported from precociously maturing Atlantic salmon parr (Maugars \& Schmitz 2008b). Finally, recent work in rainbow trout has shown that Fsh induced changes in testicular gene expression independent of its steroidogenic activity, including factors belonging to paracrine regulatory pathways (Sambroni et al. 2013).

Lh plasma levels usually increase in salmonid fish when approaching the spawning season after most of the testicular growth has been achieved (Gomez et al. 1999, Campbell et al. 2003). Still, lhb mRNA levels increased gradually during spermatogenesis, similar to previous findings in maturing male Atlantic salmon parr (Maugars \& Schmitz 2008a) or in maturing Atlantic salmon female grilse (Andersson et al. 2013). This observation is probably related to the positive feedback effect of testicular steroids on pituitary $l h b$ gene expression, being strong for testosterone and depending on its aromatization (Xiong et al. 1994, Antonopoulou et al. 2009). However, also the non-aromatizable androgen 11-KT had a (weaker) positive feedback effect on the pituitary Lh amount (Borg et al. 1998).

While the spermatogenic wave was developing faster initially in the two SW groups, this changed when in March, irrespective of the salinity, the LD groups developed faster toward completion of the wave. This was evident by the earlier decrease in the numbers of SPGB and spermatocytes and the earlier increase in the number of spermatozoa, showing that the production of new spermatogenic cysts had stopped earlier and that existing cysts completed their development earlier in the LD than in the LL groups. The males exposed to LD moreover showed 11-KT levels twice as high as the LL groups.

Published by Bioscientifica Ltd 
Based on the pituitary gene expression data, in particular with regard to the gnrhr4 and lhb transcript levels, and in the light of previous work on elevated Lh blood levels during spermiation, we propose that the stronger increase in androgen plasma levels in these groups reflects elevated Lh secretion. The short photoperiod may have activated the GNRH-Lh-androgen axis (Amano et al. 1999, 2001). It has not been clarified yet whether the additional increase in androgen levels in fully mature male salmonids is required for spermiation or can be understood in the context of secondary sexual characteristics or reproductive behavior. If acting on the testis, it may include stopping the production of differentiating spermatogenic cysts. In stickleback, prolonging the period with high androgen plasma levels postponed the restart of spermatogenesis for the next reproductive season (Andersson et al. 1988). However, stopping the production of differentiating spermatogenic cysts might also involve the downregulation of $f s h b$ mRNA (Fig. 5b) and Fsh plasma levels (Gomez et al. 1999). After all, downregulation of $f s h b$ mRNA levels can be induced by high androgen doses in Atlantic salmon parr (Antonopoulou et al. 2009).

Taken together, this study shows that Atlantic salmon postsmolts can reach sexual maturation under different environmental conditions and provides evidence for a differential activation of the brain-pituitary-testis axis, where the start of puberty is enhanced (via GNRH-Fshandrogens) by SW and completion of puberty (via GNRHLh-androgens) by short days. Hence, although salinity and photoperiod conditions clearly modulated the response, the overall result of high maturation under elevated temperatures suggests that exposure to long days at the end of the smoltification regime in combination with relatively high water temperature may be sufficient to trigger maturation.

\section{Supplementary data}

This is linked to the online version of the paper at http://dx.doi.org/10.1530/ JOE-13-0240.

\section{Declaration of interest}

The authors declare that there is no conflict of interest that could be perceived as prejudicing the impartiality of the research reported.

\section{Funding}

This study was supported by the Norwegian Research Council (contract 199518) and Norwegian Ministry of Fisheries and Coastal Affairs (contract 12622-01), Utrecht University, and the Brazilian Foundation CAPES (Coordenação de Aperfeiçoamento de Pessoal de Nível Superior).

\section{Acknowledgements}

The authors wish to thank the technical staff at the Institute of Marine Research, Matre for their excellent technical support.

\section{References}

Almeida FFL, Kristoffersen C, Taranger GL \& Schulz RW 2008 Spermatogenesis in Atlantic cod (Gadus morhua): a novel model of cystic germ cell development. Biology of Reproduction 78 27-34. (doi:10.1095/ biolreprod.107.063669)

Amano M, Ikuta K, Kitamura S \& Aida K 1999 Effects of photoperiod on salmon GnRH mRNA levels in brain of castrated underyearling precocious male masu salmon. General and Comparative Endocrinology 115 70-75. (doi:10.1006/gcen.1999.7286)

Amano M, lkuta K, Kitamura S \& Aida K 2001 Effects of photoperiod on pituitary gonadotropin levels in masu salmon. Journal of Experimental Zoology 289 449-455. (doi:10.1002/jez.1026)

Andersson E, Mayer I \& Borg B 1988 Inhibitory effect of 11-ketoandrostenedione and androstenedione on spermatogenesis in the threespined stickleback, Gasterosteus aculeatus L. Journal of Fish Biology 33 835-840. (doi:10.1111/j.1095-8649.1988.tb05530.x)

Andersson E, Schulz RW, Male R, Bogerd J, Patiña D, Benedet S, Norberg B \& Taranger GL 2013 Pituitary gonadotropin and ovarian gonadotropin receptor transcript levels: seasonal and photoperiod-induced changes in the reproductive physiology of female Atlantic salmon (Salmo salar). General and Comparative Endocrinology 191 247-258. (doi:10.1016/ j.ygcen.2013.07.001)

Antonopoulou E, Swanson P \& Borg P 2009 Effects of aromatase inhibitors and different doses of testosterone on gonadotropins in one year old male Atlantic salmon (Salmo salar). Comparative Biochemistry and Physiology. Part A, Molecular \& Integrative Physiology 153 408-416. (doi:10.1016/j.cbpa.2009.03.019)

Arnesen AM, Toften H, Agustsson T, Stefansson SO, Handeland SO \& Björnsson BTh 2003 Osmoregulation, feed intake, growth and growth hormone levels in O+ Atlantic salmon (Salmo salar L.) transferred to seawater at different stages of smolt development. Aquaculture 222 167-187. (doi:10.1016/S0044-8486(03)00109-1)

Balment RJ, Weiqun LU, Weybourne E \& Warne JM 2006 Arginine vasotocin a key hormone in Wsh salt and water balance and many other aspects of physiology and behaviour. General and Comparative Endocrinology 147 9-16. (doi:10.1016/j.ygcen.2005.12.022)

Berge AI, Berg A, Fyhn HJ, Barnung T, Hansen T \& Stefansson SO 1995 Development of salinity tolerance in underyearling smolts of Atlantic salmon (Salmo salar L.) reared under different photoperiods. Canadian Journal of Fisheries and Aquatic Sciences 52 243-251. (doi:10.1139/f95-024)

Bogerd J, Blomenröhr M, Andersson E, van der Putten HHAGM, Tensen CP, Vischer HF, Granneman JCM, Janssen-Dommerholt C, Goos HJTh \& Schulz RW 2001 Discrepancy between molecular structure and ligand selectivity of a testicular follicle-stimulating hormone receptor of the African catfish (Clarias gariepinus). Biology of Reproduction 64 1633-1643. (doi:10.1095/biolreprod64.6.1633)

Borg B, Antonopoulou E, Mayer I, Andersson E, Bergland I \& Swanson P 1998 Effects of gonadectomy and androgen treatment on pituitary and plasma levels of gonadotropins in mature Atlantic salmon, Salmo salar, parr - positive feedback control of both gonadotropins. Biology of Reproduction 58 814-820. (doi:10.1095/biolreprod58.3.814)

Bromage N, Porter M \& Randall C 2001 The environmental regulation of maturation in farmed finfish with special reference to the role of photoperiod and melatonin. Aquaculture 197 63-98. (doi:10.1016/ S0044-8486(01)00583-X)

Campbell B, Dickey JT \& Swanson P 2003 Endocrine changes during onset of puberty in male spring Chinook salmon, Oncorhynchus tshawytscha. Biology of Reproduction 69 2109-2117. (doi:10.1095/biolreprod.103. 020560) 
Chauvigné F, Verdura S, Mazón MJ, Duncan N, Zanuy S, Gómez A \& Cerdà J 2012 Follicle-stimulating hormone and luteinizing hormone mediate the androgenic pathway in Leydig cells of an evolutionary advanced teleost. Biology of Reproduction 87 1-11. (doi:10.1095/biolreprod.112. 101691)

Cobb J, Miyaike M, Kikuchi A \& Handel MA 1999 Meiotic events at the centromeric heterochromatin: histone $\mathrm{H} 3$ phosphorylation, topoisomerase II $\alpha$ localization and chromosome condensation. Chromosoma 108 412-425. (doi:10.1007/s004120050393)

Duncan NJ \& Bromage N 1998 The effect of different periods of constant short days on smoltification in juvenile Atlantic salmon (Salmo salar). Aquaculture 168 369-386. (doi:10.1016/S0044-8486(98)00363-9)

Fjelldal PG, Hansen T \& Huang T 2011 Continuous light and elevated temperature can trigger maturation both during and immediately after smoltification in male Atlantic salmon (Salmo salar). Aquaculture $\mathbf{3 2 1}$ 93-100. (doi:10.1016/j.aquaculture.2011.08.017)

Garcia de Leaniz C, Fleming IA, Einum S, Verspoor E, Jordan WC, Consuegra S, Aubin-Horth N, Lajus D, Letcher BH, Youngson AF et al. 2007 A critical review of adaptive genetic variation in Atlantic salmon: implications for conservation. Biological Reviews of the Cambridge Philosophical Society 82 173-211. (doi:10.1111/j.1469-185X.2006. 00004.x)

García-López A, Bogerd J, Granneman JC, van Dijk W, Trant JM, Taranger GL \& Schulz RW 2009 Leydig cells express FSH receptors in African catfish. Endocrinology 150 357-365. (doi:10.1210/en.20080447)

García-López A, Jonge H, Nóbrega RH, Waal PP, Dijk W, Hemrika W, Taranger GL, Bogerd J \& Schulz RW 2010 Studies in zebrafish reveal unusual cellular expression patterns of gonadotropin receptor messenger ribonucleic acids in the testis and unexpected functional differentiation of the gonadotropins. Endocrinology $1512349-2360$. (doi:10.1210/en.2009-1227)

Gomez JM, Weil C, Ollitrault M, Le Bail PY, Breton B \& Le Gac F 1999 Growth hormone (GH) and gonadotropin subunit gene expression and pituitary and plasma changes during spermatogenesis and oogenesis in rainbow trout (Oncorhynchus mykiss). General and Comparative Endocrinology 113 413-428. (doi:10.1006/gcen.1998.7222)

Good S, Yegorov S, Martijn J, Franck J \& Bogerd J 2012 New insights into ligand-receptor pairing and coevolution of relaxin family peptides and their receptors in teleosts. International Journal of Evolutionary Biology 2012 310278. (doi:10.1155/2012/310278)

Hendzel MJ, Wei Y, Mancini MA, Van Hooser A, Ranalli T, Brinkley BR, Bazett-Jones DP DP \& Allis CD 1997 Mitosis-specific phosphorylation of histone $\mathrm{H} 3$ initiates primarily within pericentromeric heterochromatin during G2 and spreads in an ordered fashion coincident with mitotic chromosome condensation. Chromosoma 106 348-360. (doi:10.1007/ s004120050256)

Hutchings JA \& Jones MEB 1998 Life history variation and growth rate thresholds for maturity in Atlantic salmon (Salmo salar). Canadian Journal of Fisheries and Aquatic Sciences 55 22-47. (doi:10.1139/d98-004)

Jonsson N \& Jonsson B 2007 Sea growth, smolt age and age at sexual maturation in Atlantic salmon. Journal of Fish Biology 71 245-252. (doi:10.1111/j.1095-8649.2007.01488.x)

Jonsson B, Jonsson N, Brodtkorb E \& Ingebrigtsen PJ 2001 Life-history traits of brown trout vary with the size of small streams. Functional Ecology 15 310-317. (doi:10.1046/j.1365-2435.2001.00528.x)

Luckenbach JA, Dickey JT \& Swanson P 2010 Regulation of pituitary GnRH receptor and gonadotropin subunits by IGF1 and GnRH in prepubertal male coho salmon. General and Comparative Endocrinology 167 387-396. (doi:10.1016/j.ygcen.2009.09.010)

Maugars G \& Schmitz M 2008a Expression of gonadotropin and gonadotropin receptor genes during early sexual maturation in male Atlantic salmon parr. Molecular Reproduction and Development $\mathbf{7 5}$ 403-413. (doi:10.1002/mrd.20767)

Maugars G \& Schmitz M 2008b Gene expression profiling during spermatogenesis in early maturing male Atlantic salmon parr testes.
General and Comparative Endocrinology 159 178-187. (doi:10.1016/ j.ygcen.2008.08.008)

Meier KM, Figueiredo MA, Kamimura MT, Laurino J, Maggioni R, Pinto LS, Dellagostin OA, Tesser MB, Sampaio LA \& Marins LF 2009 Increased growth hormone (GH), growth hormone receptor (GHR), and insulinlike growth factor I (IGF-I) gene transcription after hyperosmotic stress in the Brazilian flounder Paralichthys orbignyanus. Fish Physiology and Biochemistry 35 501-509. (doi:10.1007/s10695-008-9287-1)

Ohta T, Miyake H, Miura C, Kamei H, Aida K \& Miura T 2007 Folliclestimulating hormone induces spermatogenesis mediated by androgen production in Japanese eel, Anguilla japonica. Biology of Reproduction 77 970-977. (doi:10.1095/biolreprod.107.062299)

Olsvik PA, Lie KK, Jordal AEO, Nilsen TO \& Hordvik I 2005 Evaluation of potential reference genes in real-time RT-PCR studies of Atlantic salmon. BMC Molecular Biology 6 1-9. (doi:10.1186/1471-2199-6-21)

Oppen-Berntsen DO, Olsen SO, Rong CJ, Taranger GL, Swanson P \& Walther BT 1994 Plasma levels of eggshell ZR-proteins, estradiol-17 $\beta$, and gonadotropins during an annual reproductive cycle of Atlantic salmon (Salmo salar). Journal of Experimental Zoology 268 59-70. (doi:10.1002/jez.1402680108)

Planas JV \& Swanson P 1995 Maturation-associated changes in the response of the salmon testis to the steroidogenic actions of gonadotropins (GTH I and GTH II) in vitro. Biology of Reproduction 52 697-704. (doi:10.1095/biolreprod52.3.697)

Planas JV, Swanson P \& Dickhoff WW 1993 Regulation of testicular steroid production in vitro by gonadotropins (GTH I and GTH II) and cyclic AMP in coho salmon (Oncorhynchus kisutch). General and Comparative Endocrinology 91 8-24. (doi:10.1006/gcen.1993.1099)

Rodríguez M \& Specker JL 1991 In vitro effects of arginine vasotocin on testosterone production by testes of rainbow trout (Oncorhynchus mykiss). General and Comparative Endocrinology 83 249-257. (doi:10.1016/0016-6480(91)90028-5)

Sambroni E, Rolland AD, Lareyre J-J \& Le Gac F 2013 Fsh and Lh have common and distinct effects on gene expression in rainbow trout testis. Journal of Molecular Endocrinology 50 1-18. (doi:10.1530/JME-12-0197)

Schulz RW 1985 Measurement of 5 androgens in the blood of immature and maturing male rainbow-trout (Salmo-gairdneri Richardson). Steroids 46 717-726. (doi:10.1016/0039-128X(85)90051-0)

Schulz RW \& Nóbrega RH 2011 Anatomy and histology of fish testis. In Encyclopedia of Fish Physiology: From Genome to Environment, vol 1, pp 616-626. Ed. Anthony P Farrell. San Diego: Academic Press.

Scott AP \& Sumpter JP 1989 Seasonal variations in testicular germ cell stages and plasma concentrations of sex steroids in male rainbow trout (Salmo gairdneri) maturing at 2 years old. General and Comparative Endocrinology 73 46-58. (doi:10.1016/0016-6480(89)90054-3)

Skaar KS, Nóbrega RH, Magaraki A, Olsen LC, Schulz RW \& Male R 2011 Proteotytically activated, recombinant anti-Müllerian hormone inhibits androgen secretion, proliferation, and differentiation of spermatogonia in adult zebrafish testis organ culture. Endocrinologist 152 3527-3540. (doi:10.1210/en.2010-1469)

Skilbrei OT \& Heino M 2011 Reduced daylength stimulates size-dependent precocious maturity in $0+$ male Atlantic salmon parr. Aquaculture $\mathbf{3 1 1}$ 168-174. (doi:10.1016/j.aquaculture.2010.12.004)

Stefansson SO, Björnsson B Th, Hansen T, Haux C, Taranger GL \& Saunders RL 1991 Growth, parr-smolt transformation and changes in growth hormone of Atlantic salmon (Salmo salar) reared under different photoperiods. Canadian Journal of Fisheries and Aquatic Sciences 48 2100-2108. (doi:10.1139/f91-249)

Suzuki K, Nagahama Y \& Kawauchi H 1998 Steroidogenic activities of two distinct gonadotropins. General and Comparative Endocrinology 71 452-458. (doi:10.1016/0016-6480(88)90274-2)

Swanson P, Bernard M, Nozaki M, Suzuki K, Kawauchi H \& Dickhoff WW 1989 Gonadotropins I and II in juvenile coho salmon. Fish Physiology and Biochemistry 7 169-176. (doi:10.1007/BF00004704)

Taranger GL, Carrillo M, Schulz RW, Fontaine P, Zanuy S, Felip A, Weltzien FA, Dufour S, Karlsen O, Norberg B et al. 2010 Control of 
puberty in farmed fish. General and Comparative Endocrinology 165 483-515. (doi:10.1016/j.ygcen.2009.05.004)

Taylor EB 1991 A review of local adaptation in Salmonidae, with special reference to Pacific and Atlantic salmon. Aquaculture 98 185-207. (doi:10.1016/0044-8486(91)90383-I)

Thrush MA, Duncan NJ \& Bromage NR 1994 The use of photoperiod in the production of out-of-season Atlantic salmon (Salmo salar) smolts. Aquaculture 121 29-44. (doi:10.1016/0044-8486(94)90005-1) de Waal PP, Wang DS, Nijenhuis WA, Schulz RW \& Bogerd J 2008 Functional characterization and expression analysis of the androgen receptor in zebrafish (Danio rerio) testis. Reproduction 136 225-234. (doi:10.1530/REP-08-0055)

Xiong F, Liu D, Elsholtz HP \& Hew CL 1994 The Chinook salmon gonadotropin II $\beta$ subunit gene contains a strong minimal promoter with a proximal negative element. Molecular Endocrinology 8 771-781. (doi:10.1210/mend.8.6.7935492)

Received in final form 22 November 2013

Accepted 19 December 2013

Accepted Preprint published online 20 December 2013
Published by Bioscientifica Ltd. 